\title{
Red Cell Distribution Width Can Predict the Significance of Angiographically Intermediate Coronary Lesions
}

\author{
Sadık Kadri Açıkgöz ${ }^{a}$ Burak Açar ${ }^{a}$ Selahattin Aydına Eser Açıkgöz ${ }^{b} \quad$ Okan Er ${ }^{a}$ \\ Barış Şensoy ${ }^{a}$ Mustafa Mücahit Balci ${ }^{a}$ Çağrı Yayla ${ }^{a}$ Fatih Şen $^{a} \quad$ Salih Topal $^{b}$ \\ Sinan Aydoğdu ${ }^{a}$

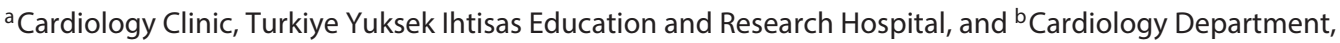 \\ Gazi University Faculty of Medicine, Ankara, Turkey
}

\section{Key Words}

Coronary artery stenosis - Fractional flow reserve .

Erythrocyte indices $\cdot$ Red cell distribution width

\begin{abstract}
Objective: In the present study, the association between red cell distribution width (RDW) with functional significance of intermediate coronary artery lesions was investigated. $\mathbf{M a}$ terials and Methods: Two hundred and forty-six consecutive patients, 168 males and 78 females, who underwent fractional flow reserve (FFR) measurement for angiographically intermediate coronary stenosis $(40-70 \%$ in quantitative coronary analysis) in the left anterior descending coronary artery were enrolled into the study. The functional significance of intermediate coronary artery lesions was determined by FFR measurement. An FFR value $<0.75$ was defined as functionally significant. Venous blood samples were taken within $48 \mathrm{~h}$ before the FFR measurement, and RDW levels were determined by a Coulter LH Series hematology analyzer. Logistic regression analysis was used to examine the association between functional significance in FFR measurement and other variables. Results: Of the 246 patients, 62 (25.2\%) exhibited significant functional stenosis (FFR $<0.75$ ) in the FFR measurement. The mean RDW level was signifi-
\end{abstract}

cantly higher in patients with significant stenosis $(14.19 \pm$ 0.73 vs. $13.69 \pm 0.77, p<0.001)$. In stepwise multivariate logistic regression analysis, $\mathrm{RDW}(\mathrm{OR}=2.489,95 \% \mathrm{Cl}=1.631-$ $3.799, \mathrm{p}<0.001)$ and male gender $(\mathrm{OR}=2.826,95 \% \mathrm{Cl}=$ $1.347-5.928, p=0.006$ ) were independent predictors of significant functional stenosis. Conclusion: Increased RDW levels were associated with functional significance of angiographically intermediate coronary artery stenoses.

(c) 2015 S. Karger AG, Basel

\section{Introduction}

Coronary angiography plays an essential role in the assessment of epicardial coronary artery lesions [1]. It is of great importance to determine the functional significance of angiographically intermediate coronary artery stenoses, because it is the most important factor regarding clinical outcome and is essential for revascularization decision $[2,3]$. However, coronary angiography has limited accuracy in defining the functional significance of a coronary artery stenosis, and fractional flow reserve (FFR) has been widely used as an accurate and lesion-specific tool which indicates the functional significance of a particular lesion [4-6].

\begin{tabular}{ll}
\hline KARGER & $\begin{array}{l}\text { ○ 2015 S. Karger AG, Basel } \\
1011-7571 / 15 / 0251-0031 \$ 39.50 / 0 \quad \text { Karger }\end{array}$ \\
E-Mail karger@karger.com & $\begin{array}{l}\text { Thisis an Open Access article licensed under the terms of the } \\
\text { Creative Commons Attribution-NonCommercial 3.0 Un- } \\
\text { ported license (CC BY-NC) (www.karger.com/OA-license), } \\
\text { applicable to the online version of the article only. Distribu- } \\
\text { tion permitted for non-commercial purposes only. }\end{array}$
\end{tabular}

Sadık Kadri Açıközz

Turkiye Yuksek Ihtisas Hastanesi

TR-06100 Sihhiye, Ankara (Turkey)

E-Maildrskad@gmail.com 
Red cell distribution width (RDW) is a readily available part of routine complete blood cell counts and a relatively novel marker of inflammation and oxidative stress [7, 8]. Previous studies [9-11] showed that RDW is associated with numerous cardiovascular conditions. Increased RDW is a negative prognostic marker in patients with heart failure, stable coronary artery disease and ST elevation myocardial infarction. A relationship between RDW and myocardial ischemia had been shown in dobutamine stress echocardiography [12]. However, the relationship between RDW and functional significance of coronary artery lesions in FFR has not been investigated. Thus, the aim of this study was to investigate the relationship between RDW and the functional significance of angiographically intermediate coronary artery stenoses.

\section{Subjects and Methods}

A total of 314 consecutive patients who underwent FFR measurement for intermediate lesions (40-70\% stenosis in quantitative coronary analysis) in the left anterior descending artery from January 2012 to June 2013 were enrolled in this study. Clinical, demographic and angiographic data of the patients were obtained from hospital records. Exclusion criteria were patients with previous myocardial infarction, history of heart failure, severe arrhythmia, anemia according to WHO criteria (hemoglobin value for males $<13 \mathrm{~g} / \mathrm{dl}$, for females $<12 \mathrm{~g} / \mathrm{dl}$ ) [13], blood transfusion in the last 6 months, acute infection, chronic kidney disease (creatinine clearance $<60 \mathrm{ml} / \mathrm{min}$ ), hematological diseases, malignancy, chronic systemic disease and patients with critical lesions in other coronary arteries and tandem lesions. Based on the exclusion criteria, 68 patients were rejected; the remaining 246 patients formed our study population. Among the participants, 144 had hypertension, and 74 had diabetes mellitus. The study was approved by the Local Ethics Committee. Venous blood samples were taken within $48 \mathrm{~h}$ before the FFR measurement for biochemical and hematological measurements including complete blood count, serum creatinine and lipid profile. The RDW levels were determined by a Coulter LH Series hematology analyzer (Beckman Coulter Inc., Hialeah, Fla., USA).

\section{FFR Measurement}

After administration of an intra-arterial heparin bolus of 5,000 units, the coronary artery was engaged using a guiding catheter without side holes. Then, a 0.014 -inch pressure monitoring guidewire (PrimeWire, Volcano, San Diego, Calif., USA) was calibrated and positioned distally to the stenosis. An intracoronary nitroglycerin bolus of $200 \mu \mathrm{g}$ was given 2 min before FFR measurement to prevent vasospasm. Baseline distal intracoronary pressure was recorded, and intracoronary adenosine was administered to induce maximum hyperemia by successively increasing the adenosine dose until no further decrement in the FFR value was observed. FFR was calculated as the ratio of mean distal intracoronary pressure to the mean aortic pressure at the time of peak hyperemia. An FFR value $<0.75$ was defined as functionally significant.

\section{Statistical Analysis}

The SPSS statistical software (SPSS 17.0 for Windows, SPSS Inc., Chicago, Ill., USA) was used for data analysis. Quantitative data are presented as means \pm standard deviation and categorical variables presented as percentages. The data were tested for normal distribution using the Kolmogorov-Smirnov test. Student's $t$ or Mann-Whitney U tests, as appropriate, were used to compare continuous variables. The $\chi^{2}$ test was used to identify statistically significant differences for categorical variables. Logistic regression analysis was used to examine the association between functional significance in FFR measurement and other variables. Variables with a $\mathrm{p}$ value of $<0.1$ in univariate logistic regression analysis were included in a multivariate logistic regression model. A 2-tailed $\mathrm{p}<$ 0.05 was considered significant.

\section{Results}

The mean age of the 246 participants was $61.4 \pm 10.9$ years. Of the 246 patients, 62 (25.2\%) exhibited significant functional stenosis, and 184 (74.8\%) exhibited nonsignificant stenosis in the FFR measurement. The mean RDW was significantly higher in patients with significant stenosis $(14.19 \pm 0.73$ vs. $13.69 \pm 0.77, \mathrm{p}<0.001)$. Other baseline variables, including use of cardiovascular medicine, were similar in both patients with significant and nonsignificant stenosis (table 1). In stepwise multivariate logistic regression analysis, RDW and male gender were independently associated with significant functional stenosis in the FFR measurement (table 2). The receiveroperating characteristic curve analysis showed that for the RDW at a cutoff point of $13.85 \%$ sensitivity and specificity were 69.4 and $65.8 \%$, respectively, in detecting significant functional stenosis in the FFR measurement (fig. 1).

\section{Discussion}

In this study, RDW levels were independently associated with functionally significant lesions using FFR measurements of angiographically intermediate coronary stenosis, and male gender was the other independent predictor of functional significance.

Functionally significant stenoses cause inducible ischemia and are associated with worse outcomes [14]. In contrast, if a stenosis has no functional significance, a favorable outcome can be expected with medical treatment [15]. FFR is linearly related to maximum blood flow to the myocardial distribution of the respective artery, and it can indicate the functional significance of a particular lesion irrespective of the factors like patient, artery and 
Table 1. Clinical, laboratory and angiographic characteristics of the patients

\begin{tabular}{|c|c|c|c|c|}
\hline & $\begin{array}{l}\text { Nonsignificant } \\
\text { stenosis }(\mathrm{n}=184)\end{array}$ & $\begin{array}{l}\text { Significant } \\
\text { stenosis }(n=62)\end{array}$ & $\begin{array}{l}\text { All } \\
(\mathrm{n}=246)\end{array}$ & $\mathrm{p}$ value \\
\hline Age, years & $61.0 \pm 10.3$ & $62.77 \pm 12.4$ & $61.4 \pm 10.9$ & 0.278 \\
\hline \multicolumn{5}{|l|}{ Gender } \\
\hline Male & $120(65.3)$ & $48(77.5)$ & $168(68.3)$ & 0.074 \\
\hline Female & $64(34.7)$ & $14(22.5)$ & $78(31.7)$ & \\
\hline Hypertension & $110(59.7)$ & $34(54.8)$ & $144(58.5)$ & 0.494 \\
\hline Diabetes mellitus & $54(29.3)$ & $20(32.2)$ & $74(30.1)$ & 0.666 \\
\hline Smoking & $68(36.9)$ & $30(48.3)$ & $98(39.8)$ & 0.112 \\
\hline Hemoglobin, g/dl & $14.13 \pm 1.67$ & $13.84 \pm 1.39$ & $14.03 \pm 1.60$ & 0.218 \\
\hline $\mathrm{MCV}, \mathrm{fl}$ & $88.2 \pm 4.4$ & $88.8 \pm 5.0$ & $88.3 \pm 4.6$ & 0.415 \\
\hline RDW, \% & $13.69 \pm 0.77$ & $14.19 \pm 0.73$ & $13.82 \pm 0.79$ & $<0.001$ \\
\hline WBC & $8,313 \pm 2,188$ & $8,778 \pm 2,134$ & $8,430 \pm 2,179$ & 0.147 \\
\hline Platelets $(× 1,000)$ & $274.3 \pm 74.3$ & $290.0 \pm 91.4$ & $278.3 \pm 79.0$ & 0.176 \\
\hline Creatinine, $\mathrm{mg} / \mathrm{dl}$ & $1.09 \pm 1.29$ & $1.11 \pm 1.44$ & $1.10 \pm 1.35$ & 0.123 \\
\hline Total cholesterol, mg/dl & $187.4 \pm 42.4$ & $189.1 \pm 46.9$ & $187.8 \pm 43.5$ & 0.780 \\
\hline LDL-C, mg/dl & $115.4 \pm 38.5$ & $117.6 \pm 38.9$ & $116.0 \pm 38.6$ & 0.693 \\
\hline $\mathrm{HDL}-\mathrm{C}, \mathrm{mg} / \mathrm{dl}$ & $40.7 \pm 11.3$ & $42.6 \pm 9.3$ & $41.2 \pm 10.9$ & 0.245 \\
\hline Triglyceride, mg/dl & $163.1 \pm 92.6$ & $140.9 \pm 81.6$ & $157.5 \pm 90.3$ & 0.095 \\
\hline Statin & $39(21.2)$ & $12(19.4)$ & $51(20.7)$ & 0.757 \\
\hline ACE-I & $54(29.3)$ & $16(25.8)$ & $70(28.5)$ & 0.593 \\
\hline$\beta$-Blocker & $24(13.0)$ & $10(16.1)$ & $34(13.8)$ & 0.543 \\
\hline Calcium channel blocker & $38(20.7)$ & $12(19.4)$ & $50(20.3)$ & 0.826 \\
\hline Aspirin & $59(32.1)$ & $22(35.5)$ & $81(32.9)$ & 0.620 \\
\hline Diameter of stenosis, $\%$ & $55.05 \pm 9.69$ & $56.77 \pm 10.2$ & $55.49 \pm 9.83$ & 0.234 \\
\hline
\end{tabular}

Table 2. Factors predicting functional significance in logistic regression analysis

\begin{tabular}{|c|c|c|c|c|}
\hline \multirow[t]{2}{*}{ Variables } & \multicolumn{2}{|l|}{ Univariable } & \multicolumn{2}{|l|}{ Multivariable } \\
\hline & OR & $\mathrm{p}$ value & OR & $\mathrm{p}$ value \\
\hline Age & $1.015(0.988-1.042)$ & 0.278 & - & - \\
\hline Male gender & $1.829(0.937-3.567)$ & 0.077 & $2.826(1.347-5.928)$ & 0.006 \\
\hline Hypertension & $1.224(0.685-2.188)$ & 0.495 & - & - \\
\hline Diabetes mellitus & $1.146(0.617-2.131)$ & 0.666 & - & - \\
\hline Percent diameter stenosis & $1.018(0.988-1.049)$ & 0.234 & & \\
\hline Hemoglobin & $0.964(0.909-1.022)$ & 0.218 & - & - \\
\hline $\mathrm{WBC}$ & $1.000(1.000-1.000)$ & 0.147 & - & - \\
\hline MCV & $1.026(0.964-1.093)$ & 0.414 & - & - \\
\hline RDW & $2.218(1.498-3.283)$ & $<0.001$ & $2.489(1.631-3.799)$ & $<0.001$ \\
\hline Platelets & $1.000(1.000-1.000)$ & 0.177 & - & - \\
\hline Creatinine & $1.379(0.445-4.273)$ & 0.124 & - & - \\
\hline LDL-C & $1.002(0.994-1.009)$ & 0.692 & - & - \\
\hline HDL-C & $1.016(0.989-1.042)$ & 0.245 & - & - \\
\hline Triglyceride & $0.997(0.993-1.001)$ & 0.098 & $0.997(0.994-1.001)$ & 0.164 \\
\hline
\end{tabular}

Figures in parentheses indicate 95\% CI. WBC = White blood cell; MCV = mean corpuscular volume; LDL-C = low density lipoprotein cholesterol; HDL-C = high density lipoprotein cholesterol. 


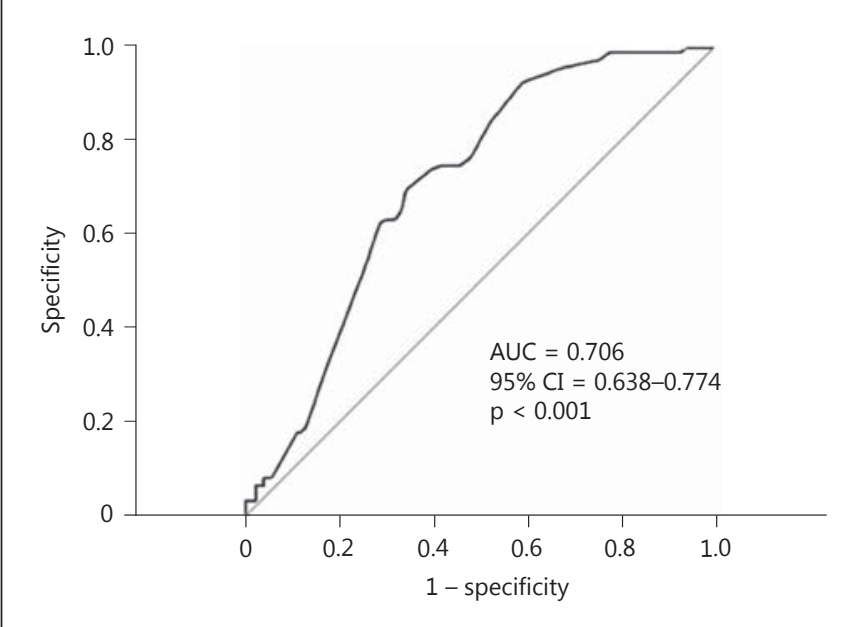

Fig. 1. The receiver-operating characteristic curve analysis for red cell distribution in predicting functionally significant coronary stenosis in FFR measurements.

blood pressure [16]. FFR is established as the gold standard for the assessment of the significance of a coronary stenosis $[16,17]$. Thus, we chose FFR to determine the functional significance of coronary lesions and its relationship with the RDW level.

The mechanism of the increased RDW in functionally significant coronary artery stenosis is not clear. It is possible that ischemia caused by functionally significant lesions is responsible for increased inflammation and oxidative stress, and, thus, leads to increased RDW. It is known that inflammation impairs iron metabolism and inhibits the response to erythropoietin [18]. Tumor necrosis factor $\alpha$ and interleukin 6 are responsible for the attenuation of the activity of erythropoietin and the production of ineffective red blood cells (RBCs) [7]. Inflammation may also lead to an increase in RDW by disturbing the red cell membrane and inducing changes in RBC maturation [18]. Oxidative stress causes shortened RBC survival by increasing the fragility of RBCs [19] and decreasing the rate of erythroid maturation [20]. The result of the shortened RBC survival is increased RDW. In addition, increased RDW was found to be associated with impaired RBC deformability and increased blood viscosity, and such hemorheological alterations may cause slow coronary flow and contribute to the myocardial ischemia $[21,22]$.

Male gender was the other predictor of functional significance in our study. Previously, Fineschi et al. [23] demonstrated that despite similar clinical and angiographic characteristics, male patients have significantly lower FFR values in response to adenosine. However, the mechanism of this observation remains to be established.

Previous studies revealed the value of RDW in various cardiovascular settings. Higher RDW levels predicted stent restenosis, contrast-induced nephropathy and increased mortality in patients undergoing percutaneous coronary intervention $[11,24,25]$. Furthermore, increased RDW is associated with poor clinical outcomes, mortality and recurrent myocardial infarction in patients with acute coronary syndrome [25-28]. Our study is another one to show the possible use of RDW in cardiology practice. Since patients with functionally significant coronary stenosis have relatively worse outcomes [14], increased RDW levels may also indicate poor clinical outcomes in our study population. However, further studies with long-term follow-up are required to show such an association.

The main limitation of this study was its single-center and retrospective design. Therefore it is not possible to distinguish between association and causal relationship when interpreting its results. Another limitation of the study was that serum vitamin $B_{12}$, folate and iron levels which might influence RDW were not measured. Oxidative stress and inflammation were not assessed by different markers since RDW has been established as an independent marker of inflammation and oxidative stress.

\section{Conclusion}

The results of the current study showed that RDW were independently associated with functional significance of intermediate coronary artery stenoses in FFR measurements. Further studies are needed to elucidate the exact role of RDW in predicting functionally significant coronary artery disease.

\section{Disclosure Statement}

There are no conflicts of interest.

References
34
Med Princ Pract 2016:25:31-35 DOI: $10.1159 / 000441001$
Açıkgöz/Açar/Aydın/Açıkgöz/Er/Şensoy/ Balci/Yayla/Şen/Topal/Aydoğdu 
3 Metz LD, Beattie M, Hom R, et al: The prognostic value of normal exercise myocardial perfusion imaging and exercise echocardiography: a meta-analysis. J Am Coll Cardiol 2007;49:227-237.

-4 Topol EJ, Nissen SE: Our preoccupation with coronary luminology. The dissociation between clinical and angiographic findings in ischemic heart disease. Circulation 1995;92: 2333-2342.

5 Pijls NH, van Son JA, Kirkeeide RL, et al: Experimental basis of determining maximum coronary, myocardial, and collateral blood flow by pressure measurements for assessing functional stenosis severity before and after percutaneous transluminal coronary angioplasty. Circulation 1993;87:1354-1367.

6 De Bruyne B, Baudhuin T, Melin JA, et al: Coronary flow reserve calculated from pressure measurements in humans. Validation with positron emission tomography. Circulation 1994;89:1013-1022.

7 Ferrucci L, Guralnik JM, Woodman RC, et al: Proinflammatory state and circulating erythropoietin in persons with and without anemia. Am J Med 2005;118:1288.

-8 Semba RD, Patel KV, Ferrucci L, et al: Serum antioxidants and inflammation predict red cell distribution width in older women: the Women's Health and Aging Study I. Clin Nutr 2010;29:600-604

-9 Felker GM, Allen LA, Pocock SJ, et al: Red cell distribution width as a novel prognostic marker in heart failure: data from the CHARM Program and the Duke Databank. J Am Coll Cardiol 2007;50:40-47.

10 Cavusoglu E, Chopra V, Gupta A, et al: Relation between red blood cell distribution width (RDW) and all-cause mortality at two years in an unselected population referred for coronary angiography. Int J Cardiol 2010;141: 141-146.
11 Uyarel H, Ergelen M, Cicek G, et al: Red cell distribution width as a novel prognostic marker in patients undergoing primary angioplasty for acute myocardial infarction. Coron Artery Dis 2011;22:138-144.

12 Akilli H, Kayrak M, Aribas A, et al: The relationship between red blood cell distribution width and myocardial ischemia in dobutamine stress echocardiography. Coron Artery Dis 2014;25:152-158.

13 Nutritional anaemias. Report of a WHO scientific group. World Health Organ Tech Rep Ser 1968;405:5-37.

14 Shaw LJ, Heller GV, Casperson P, et al: Gated myocardial perfusion single photon emission computed tomography in the Clinical Outcomes Utilizing Revascularization and Aggressive Drug Evaluation (COURAGE) trial, Veterans Administration Cooperative study No 424. J Nucl Cardiol 2006;13:685-698.

-15 Pijls NH, van Schaardenburgh P, Manoharan $\mathrm{G}$, et al: Percutaneous coronary intervention of functionally nonsignificant stenosis: 5-year follow-up of the DEFER Study. J Am Coll Cardiol 2007;49:2105-2111.

16 Pijls NH, Sels JW: Functional measurement of coronary stenosis. J Am Coll Cardiol 2012;59: 1045-1057.

17 De Bruyne B, Pijls NH, Kalesan B, et al: Fractional flow reserve-guided PCI versus medical therapy in stable coronary disease. N Engl J Med 2012;367:991-1001

18 Weiss G, Goodnough LT: Anemia of chronic disease. N Engl J Med 2005;352:1011-1023.

19 Tozzi-Ciancarelli MG, Di Giulio A, TroianiSevi E, et al: Human erythrocyte damage at the initial stages of oxidative stress. Cell Biophys 1989;15:225-234.
20 Marinkovic D, Zhang X, Yalcin S, et al: Foxo3 is required for the regulation of oxidative stress in erythropoiesis. J Clin Invest 2007; 117:2133-2144.

21 Patel KV, Mohanty JG, Kanapuru B, et al: Association of the red cell distribution width with red blood cell deformability. Adv Exp Med Biol 2013;765:211-216.

22 Kalay N, Aytekin M, Kaya MG, et al: The relationship between inflammation and slow coronary flow: increased red cell distribution width and serum uric acid levels. Turk Kardiyol Dern Ars 2011;39:463-46823.

23 Fineschi M, Guerrieri G, Orphal D, et al: The impact of gender on fractional flow reserve measurements. Eur Interv 2013;9:360-366.

24 Kurtul A, Murat SN, Yarlioglues M, et al: The association of red cell distribution width with in-stent restenosis in patients with stable coronary artery disease. Platelets 2015;26:48-52.

25 Kurtul A, Yarlioglues M, Murat SN, et al: Red cell distribution width predicts contrast-induced nephropathy in patients undergoing percutaneous coronary intervention for acute coronary syndrome. Angiology 2015;66:433440

26 Dabbah S, Hammerman H, Markiewicz W, et al: Relation between red cell distribution width and clinical outcomes after acute myocardial infarction. Am J Cardiol 2010;105: 312-317.

27 Lippi G, Filippozzi L, Montagnana M, et al: Clinical usefulness of measuring red blood cell distribution width on admission in patients with acute coronary syndromes. Clin Chem Lab Med 2009;47:353-357.

28 Nabais S, Losa N, Gaspar A, et al: Association between red blood cell distribution width and outcomes at six months in patients with acute coronary syndromes. Rev Port Cardiol 2009; 28:905-924. 